\title{
The Cultural Values in Texts of English Coursebooks for Junior High School in Ambon, Moluccas-Indonesia
}

\author{
Rosina Fransisca J. Lekawael ${ }^{1 *}$, Emzir $^{2}$, Zainal Rafli ${ }^{3}$ \\ ${ }^{1}$ English Department, FKIP - Universitas Pattimura, Ambon, Moluccas, Indonesia. \\ ${ }^{2 \& 3}$ Applied Linguistics, Postgraduate of Universitas Negeri Jakarta, Indonesia
}

Corresponding Author: Rosina Fransisca J. Lekawael, E-mail: rosina_lekawael@yahoo.com

\section{ARTICLE INFO}

\section{Article history}

Received: December 10, 2017

Accepted: February 15, 2018

Published: April 30, 2018

Volume: 9 Issue: 2

Advance access: March 2018

Conflicts of interest: None

Funding: None

\begin{abstract}
This study aimed at investigating and understanding the cultural values in texts of English coursebooks in Ambon, Moluccas, Indonesia. The researchers used content analysis method to analyze data in depth, detailed, and complete about the cultural values. The result of this research revealed that the cultural values from texts view found in the English coursebooks were prestige, honesty, discipline, alignment, individuality, diversity, hard-working, generosity, creativity, beauty, equality, fighting spirit, mutual help, caring, proud, independent, and belief. Thus, there were three dominant values that are, diversity, beauty, and alignment. Those results lead to implication that English teacher can apply the cultural values in teaching processes. Then, for the further language researchers can conduct related research on the impact of the cultural values to the attitude and the teenagers' age.
\end{abstract}

\section{Key words:}

Cultural Values,

English Coursebooks,

Content Analysis

\section{INTRODUCTION}

Culture has become a global issue and concern of ELT researchers in the world. In the Middle East areas, it is clear that English culture through textbooks could not be taught separately from the English language. As Awayed-Bishara (2015:540) assumed that the cultural content of materials used for teaching English to high school speakers of Arabic in Israel were more contained of the western culture than Arabic. This affected misperceptions on non-native speakers as minority to maintain their ideology and power. On the other hand, Gorjian \& Aghvami (2017:77) did a comparative study beyond perceptions of EFL teachers and learners to investigate how importance English culture to improve students' reading comprehension ability. The results of comparing English materials of native and non-native textbooks indicated that the first performed more cultural content for almost all students in class than the second. It assumed that English language culture is a vital necessity in ELT. These cultural researches will enrich students' understanding on English culture as an essential aspect in teaching learning processes of English as a foreign language (EFL).

In Indonesia, English is a main subject to be learned by students in junior high school. Although, English has taught at school but their understanding level has not maximized yet. In specific areas of Indonesia, especially in Ambon city, it was less desired by students because of they face difficulties to understand its vocabularies and grammar. Besides, they have insufficient knowledge about foreign culture as result of learning foreign language that is English. They are hoped to study about language and culture once through education. School is a place where the teacher meets with students who came from different background such as areas, social classes, languages, religions, traditions, and behaviors in a homogenous society. English language is used as a media of communication to transfer ideas, thoughts, and opinions based on the students' background. Thus, this study conducted to identify the existence of the cultural values through reading materials in three English coursebooks in Ambon, Moluccas, Indonesia.

From the preliminary study by using the questionnaires, the researcher found that teachers tended to replace foreign culture materials into local materials to help students in getting ideas on text genres materials. The main reason is that the students have less background knowledge of cultures from local and foreign countries. To support them, many materials in English coursebooks should be revised by using selected cultural and contextual topics in teaching English language for students of junior high school. To be a professional English teacher, she/he has a key role to encourage students' enthusiasm not only to study about English lin- 
guistically but also they are motivated to be eager with its culture. This means that the teacher should be hard work in preparing ELT materials which is included cultural values to be taught to all students.

\section{LITERATURE REVIEW}

The awareness of cultural values from west cultures could not be avoided by English learners. This article concerned on to motivate junior high school students on learning culture through English materials. A way to teach culture to students is by using coursebooks contain of cultural values. The English material as the research subject here would be focused on cultural values-oriented learning as an emerged material to be focused in ELT in Indonesia.

Cultural values as the main goal of this research, is started by a definition of culture. Reisinger and Turner (2003:9) said that culture has also been viewed as information (Kluckhohn and Kelly, 1945) and a communication system (Hall, 1959). Several anthropologists suggest a relationship between culture and language (Kluckhohn, 1944). Language, the 'symbolic guide to culture' (Sapir, 1964, p. 70) transmits values, beliefs, perceptions, norms (Samovar et al., 1981, p. 141) and facilitates man's perception of the world (Sapir, 1964).

Culture is part of system in studying language, which contains information and values. On the contrary, language is spoken to express about certain culture. Thus, culture can be understood as all aspects of human's life such as belief, economy, social, politics, etceteras. Besides, culture could produce perception, thoughts, ideas, or norms for the society. Those aspects are expressed through verbal communication which is called as language.

In ELT, English language should be defined in wider context because of it emphasized not only the language and its grammar, but also it pushed students' knowledge on cross cultural understanding through the cultural values. This may be impacted to communication competence improvement about English and the cultural values they studied through the coursebooks.

The main problem of this research was to identify the cultural values contained in English coursebooks for junior high school grade VIII. These coursebooks were chosen for they had more dominant of west cultural content especially on genres. The major goal of this research was to investigate comprehensively the cultural values in texts of three English coursebooks for Junior High School Grade VIII in Ambon, Moluccas, Indonesia. Therefore, this research was conducted to increase students' understanding about the cultural values through texts genres.

\section{Culture and English Teaching in Indonesia}

Culture lives with human. Matsumoto and Juang (2013:226) said that human are intentional agents, having the ability to infer intentions in others, and language aids in our ability to communicate intentions, and our beliefs about the intentions of others, to each other quickly and efficiently. These abilities come together to help humans form human cultures.
In studying English as a foreign language, students explore culture about England. Kramsch (1998:3) examined that language is a system of signs that is seen as having itself a cultural value. Speakers identify themselves and others through their use of language; they view their language as a symbol of their social identity. The prohibition of its use often perceived as a rejection of their social group and their culture. Thus we can say that language symbolizes cultural reality. By language, learning process and culture awareness can assist students in transferring their experiences, ideas and attitudes, as implementation of learning and cultural meaning.

As formal education in Indonesia, English functions as second language (SL) and foreign language (FL). It means that some areas use English as second language (SL) and others use it as foreign language (FL). It is caused by Indonesia has thousands languages spread in its archipelago. English was established by government as one of main subjects for all education levels aimed at preparing young generation in future global competition. Students can use English as a means to introduce Indonesia's culture in the world. To fulfill a need of English mastery, it is recommended to use good and qualified learning materials.

As a foreign language, English is learned through textbook recommended by educational institution of Indonesia, in this case primary schools. Coursebooks contain not only information and knowledge of language to stimulate students' competency, but also design of syllabus guiding teachers in teaching based on standard competence that has been determined previously. There are many advantages of textbooks caught in supporting directed, effective and efficient learning processes in classroom.

When teaching English to students, teacher must consider the students' mother language or first language and their culture. Teaching is about to transfer knowledge of English from someone who has competency and creativity in teaching. A success teaching depends on teacher's competency in transferring prepared learning materials into a meaningful learning to students. Therefore, materials of language and culture must be integrated in learning processes to increase the students' linguistics ability and also communicative competency through culture.

\section{Cross Cultural Understanding through the English Course Book}

Cross cultural understanding (CCU) should be taught to students in junior high school level in specific areas such as Moluccas province, Indonesia. Reisinger and Turner (2003:19) said that cross-cultural differences may be noticed in social categories such as role, status, class, hierarchy, attitudes towards human nature, activity, time, and relationships between individuals. By studying it, the students are motivated to bear in mind that culture aspect could not be separated from English. We can recognize cross cultural understanding when two different languages meet, that is local language and foreign language. This study is emphasized on development of linguistic competency and cross cultural understanding which consist of present foreign culture awareness by learning its language. 
In globalization era, this big world as if demands human to increase high intensity so that they may connect with outside people or others' cultures. To emphasize here that culture is a proof of a country inheritance that must be preserved. It can't be denied that traditional or national or international culture, values, norms, and customs can change every time.

Teacher has control roles in preparing and constructing ELT materials with cultural content. To fulfill this task, teacher must have good characteristics as quoted by Brown (2007:491) that are: (1) technical knowledge such as English grammar, basic principles of language learning and teaching, fluent competence of four skills; (2) pedagogical skills such as understand and use approaches, techniques, materials, design and evaluation of language teaching; (3) interpersonal skills such as aware of cross-cultural differences of students, show enthusiasm, warmth, cooperation; (4) personal qualities such as well-organized and flexible for career improvement sake. It can be concluded that a good teacher must have certain competencies in order to present cultural content, besides the competencies mention formerly in English textbook.

Coursebook, or also called as textbook, has position as a key component in some other languages learning. It is a guide which students receive input of language and its practices in teaching learning processes in classroom. It is time to consider cultural values contained in the coursebooks. Cultural themes force the students to have competencies of culture knowledge and ability to adapt with socio-culture situation around them. If they can adapt with the environment, it is hoped that they would achieve social fluency and good personal in global society.

On the other hands, cross cultural understanding through English coursebooks can help to create certain values to be chosen or refused by other cultures. Cross culture motivate human to communicate well, and finally, it can bound relationship between one to another as a unique self-man and community.

\section{The Cultural Values from Texts View}

Why are cultural values important to be taught at school? Cultural value is a point to get meaning, quality, value, or nature of human cultures. We know that culture in general is regarded as soul of all culture forms. On the contrary, culture practically is more emphasized on customs or norms to arrange human's life.

According to Nieto (2010:136) that culture is complex an intricate; it includes content or product (the what of culture), process (how it is created and transformed), and the agents of culture (who did responsible for creating and changing it). Culture cannot be reduced to holidays, foods, or dances, although these are, of course, elements of culture. This definition also makes it clear that everyone has a culture because all people participate in the world through social and political relationships informed by history as well as by race, ethnicity, language, social class, gender, sexual orientation, and other circumstances related to identity and experience.

Therefore, to get knowledge of communicative foreign language it must involve culture aspects in learning the lan- guage. Yuen (2011:459) mentioned that learning a foreign languge involves learning different aspects of the culture in which the language is used and sometimes also how other cultures are represented in that particular culture because language depicts culture of its own and other cultures too. It means that English learning must involve all culture aspects to be used and to express how the other cultures presented into certain local culture. Language that used can picture either its cultures or others too.

According to Cortazzi and Jin in Hinkel (1999:204) there were three patterns in English textbooks reflecting cultures (C). C1 refers to learners' own culture, the source culture. C2 refers to a target culture where the target culture is used as a first language. C3 refers to cultures that are neither a source culture nor a target culture; these are a variety of cultures in English- or non-English speaking countries around the world using English as an international language. This might be termed international target cultures. These categories indicate that EFL materials contain of culture information from many countries. First, EFL materials include source/local culture means that there are materials from students' first language and culture. For example, EFL materials are produced locally. Second, EFL materials include target culture are materials describe about cultures from USA or England. Third, EFL materials include international target culture are materials picture about cultures from countries that use English as an international language such as Africa, Asia, Europe, and others. On the other hands, Allport, Vernon and Lidzey in Suriasumantri (2005:263) identified six basic cultural values in culture that are, the theoretical, the economic, the esthetic, the social, the political, and the religious.

In daily life, these values have standards about which values are more important and which values are not. We can say that every value is determined differently based on context where it is used. Six basic cultural values are tightly related to education where students can learn a language and also culture. Teacher plays role to select which cultural values to be developed in English learning based on students' needs in the future.

This present research is conducted to investigate the cultural values in texts of English coursebooks for junior high school grade VIII. The concepts of text are wide. Fairlough (1995:4) mentioned that a text is traditionally understood to be a piece of written language - a whole work such as a poem or a novel, or a relatively discrete part of a work such as a chapter. A rather broader conception has become common within discourse analysis, where a text may be either written or spoken discourse, so that, for example, the words used in a conversation (or their written transcription) constitute a text. In cultural analysis, by contrast, texts do not need to be linguistic at all; any cultural artifact - a picture, a building, a piece of music - can be seen as a text.

Text is a piece of written language through structural readings to communicate an event, a thing, a place, a person, or certain culture. Texts' analysis n this research focused on three text genres are descriptive, recount and narrative. First, descriptive text is to describe about a thing, a place and a person. Second, recount text is about personal experiences 
of someone when he/she was in some events chronologically. Third, narrative text is text contains of stories about an event or an activity related to some customs in certain areas. Therefore, those English coursebooks contain of the cultural values, as mentioned previously. The cultural values have been analyzed based on text genres and cultural types too.

\section{Research on the Cultural Content of English Coursebooks}

Since English is used as a lingua franca in over the world, its role appears significantly, especially in intercultural language teaching. Tajeddin and Teimournnezhad (2015:182) quoted that in intercultural language teaching, language learners are made aware of their own culture and are helped not only to interpret and understand a variety of other cultures Kilickaya (2004) but also to express their own cultural identity Kubota (1998). An introduction of one new language into a society is similar to recognize others' cultural aspects by the society. This new recognition is caused by a language external factor that is called as culture or custom.

Ndurra (2004:143) did a cultural study which emphasized on analysis of English textbook and culture bias in West America. He presents about the evaluation of textbook through stereotypes and culture bias, and also to discuss how they are implicated to students at school. This result indicates that a strong learning is to integrate the students' experiences into learning materials in order to improve knowledge and wide culture insight. By using textbook, the students are challenged to see the truth of culture bias and stereotypes, then to discuss the problems to avoid misperception.

Yuen (2011:458) did research to investigate whether the representation of foreign cultures in textbooks used by students of senior high school in Hongkong reflected the status of English as an international language. In order to do this, references to foreign cultures were categorized into four aspects: products, practices, perspectives, and persons. It was found overall that the representation favored the cultures of English-speaking countries, while the cultures of Africa were underrepresented. The selection of English language textbooks and the implications for redressing the imbalance in cultural content are discussed.

Yaqoob dan Zubair (2012:529) study about culture, class, and power based on critical discourse analysis in English textbook used in Pakistan. To do research, they use textbooks published by Punjab textbook board and Oxford University edition. The first is for non-elite school. While, the second book is for elite school in Pakistan. English learning and west culture were attracted the students from non-elite. On the contrary, textbook from Punjab edition which is used by elite school tend to force the students to learn more about local culture than west culture. These students have an opportunity to have power on low and middle social class either in economy or politic.

Rodriguez (2015:167) studies about cultural content in English textbook for students of language program at university in Colombia. The aim of this research is to evaluate textbook from surface and deeper culture aspects. The result shows that the textbook focused on static topics rather than introduced culture in small scale. Therefore, this research would be recommended to English teachers to pay attention on culture aspects in their teaching in order to develop interlanguage competencies of students in classroom.

Tajeddin \& Teimournezhad (2015:180) explored the hidden agenda in the representation of culture in international and ELT textbook. The aim of this study was to investigate the representation of culture in dialogues and reading passages in international and textbook used in Iran where localization is favored by language education policymakers in their macro-planning. The analysis revealed that most of the cultural elements embodied in the textbooks were culturally neutral in that they did not clearly refer to any particular culture and only a few were based on the TL and other cultures. Furthermore, in textbook corpus, first language/local culture did not feature at all, while sociological values were highlighted more than the aesthetic aspects of culture. In contrast, the main focus in the international textbooks was on intercultural elements, two-thirds of which were in the aesthetic category. TL cultural elements were comparatively more evident in the international textbooks while very few representations were culturally neutral. Thus, both textbooks, which are international and ELT textbooks, had not appropriate references with source cultures of students.

Based on the previous researches above, it can be synthesized that all of them have similar content that is to identify cultural content representation in ELT textbooks by using content analysis method and also critical discourse analysis conducted in some countries. There were some weaknesses that are those researches did not explore the cultural values comprehensively based on six basic cultural values. From the research concepts, this present study was conducted to investigate the cultural values which consist of the theoretical, the economic, the esthetic, the social, the political, and the religious in English coursebooks for junior high school grade VIII in Ambon, Moluccas, Indonesia.

\section{Methodology}

The purpose of this qualitative research was to investigate comprehensively the cultural values in texts of three English coursebooks for junior high school grade VIII in Ambon, Moluccas, Indonesia. The researchers use content analysis method to analyze data in depth, detailed, and complete about the cultural values. The reason of choosing the students at junior high school because of they were easy to be affected by negative impacts of foreign cultures. This qualitative content analysis was not tied to certain place. And the research time from data collection until data analysis was one year.

\section{The Corpus}

There were three selected coursebooks to be analyzed in the study (see Appendix 1). The parameters for the corpus selection and the description of each group of English coursebooks are shown in the following:

- The coursebooks are a series edition from Indonesia Erlangga publication which is compiled by local experts 
such as English teachers cooperated with IALF institution.

- They were approved by the Ministry of Education and distributed to various junior high schools in Indonesia.

- $\quad$ They are used junior high students especially at grade 8 in Indonesia areas.

- The primary level coursebooks were selected since cultural elements become more concerned with basic language knowledge.

\section{Data Analysis Framework}

This research used content analysis method to analyze data. Data were collected by: formulate problems and research questions based on research focus, construct theories and methodology, read all coursebooks carefully, categorize the texts, analyze cultural values of texts, recheck the analysis results, interpret the results of cultural values, and do authenticity of data. The authenticity data was using credibility criterion by triangulation, especially source triangulation. The triangulation source was conducted by recheck data from one informant to the other informants.

\section{RESULT AND DISCUSSION}

This research was based on source data of three English coursebooks for junior high school grade VIII in Ambon, Moluccas, Indonesia. This text analysis found that there were six basic cultural values that are, the theoretical, the economic, the esthetic, the social, the political, and the religious. It is based on research focus that is cultural values which were viewed from the texts and comparison in three textbooks. This text analysis showed different distribution of cultural values based on six basic cultural values, as described in the following diagram.

Figure 1 shows that the cultural values found in $\operatorname{EOS} 2$ were 14 (56\%), FS $2 A \& 2 B$ were 7 (28\%), and $W E R B$ were $4(16 \%)$. These results indicate that EOS 2 contains rich cultural values to compare with other coursebooks. This book can function to help the students in understanding about six basic cultural values. Second, the findings on the cultural values of English coursebooks can improve the students' understanding on the text genres too. In EOS 2, it was found that there were eight values based on five basic cultural values. Five basic cultural values were the theoretical, the economic, the esthetic, the social, and the political. The cultural values of texts appeared in EOS 2 were prestige, diversity, generosity, creativity, discipline, equality, fighting spirit, and belief. In $F S 2 A \& 2 B$, it was found that there were four values based on three basic cultural values. Three basic cultural values were the esthetic, the social, and the religious. The cultural values of texts appeared in FS $2 A$ and $2 B$ were hard-working, beauty, alignment, and diversity. In $W E R B$, it was found that there were four values based on four basic cultural values. Four basic cultural values were the economic, the esthetic, the social, and the religious. The cultural values of texts appeared in WERB were honesty, beauty, proud, and independent.

So, those cultural values that were needed to be learned by the students could be categorized in two groups that are,

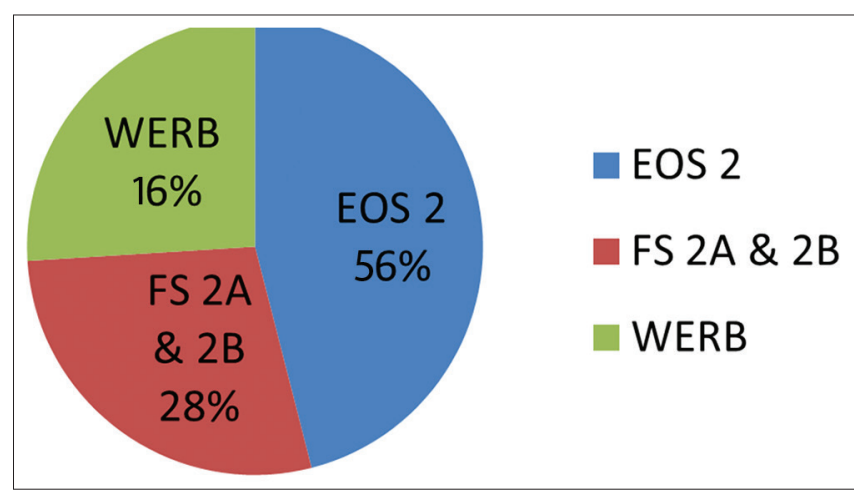

Figure 1. Cultural values in three English coursebooks

west and local cultural values. The west cultural values were prestige, honesty, discipline, alignment, individuality, and belief. On the other hands, the local cultural values were diversity, hard-working, generosity, creativity, beauty, equality, fighting spirit, mutual help, caring, proud, and independent. In addition, the texts were dominated by the cultural values in social and esthetic that are, diversity, beauty, and alignment. These values were useful to motivate the students to know about the cultural values in texts of English coursebooks (west culture) and to respect both cultures differences.

The researchers also found that texts of three English coursebooks adopt negative cultural values from west culture. These negative values presented as a result of using authentic materials from west culture into the English coursebooks. Therefore, Sidhakarya and Pratiwi (2015:249) stated that one of the best materials to be used in the classroom is authentic materials depicting how native speakers act and talk in their own social setting and environments with values all associated with their culture. Some of the cultural values are individuality (in family) and alignment (bossy, moody, bully).

\section{CONCLUSION}

Based on the result and discussion, it can be concluded that the cultural values are really presented in texts of three English coursebooks. The cultural values found were prestige, honesty, discipline, alignment, individuality, diversity, hard-working, generosity, creativity, beauty, equality, fighting spirit, mutual help, caring, proud, independent, and belief. In addition, the texts were dominated by the cultural values in social and esthetic that are, diversity, beauty, and alignment. As Tajeddin and Teirmournezhad (2015:182) stated that textbooks thus convey sets of cultural values. By understanding the cultural values in texts can rebuild students' culture awareness in studying English as a foreign language (EFL).

English teaching that prioritizes the application of cultural values in coursebooks provides an opportunity for teachers to creatively create ELT materials that are positive as a source of learning materials, and provides a broad understanding of cultural values. Learning cultural values through English coursebooks can direct students' behavioral ways in society. The values serve to regulate students when establishing communication relationships 
with others inside or outside their environment. Those results lead to implication that English teacher can apply the cultural values in teaching processes. Then, for the further language researchers could conduct related research on the impact of the cultural values to the attitude and the teenagers' age.

\section{ACKNOWLEDGEMENTS}

Creating this chapter has been a collaborative effort. I extend gratitude to all who contributed to the manuscript's development, especially the classroom teachers who inspired to finish this chapter a lot. I also offer special thanks to Indonesia Research and Technology Department that provided scholarship along the present study. Then, the Educational Department of Moluccas province and Municipality of Ambon city who had given recommendation to the researcher took data. Finally, the primary school teachers who contributed filled the questionnaires.

\section{REFERENCES}

Awayed-Bishara M. (2015). Analyzing the Cultural Content of Materials Used for Teaching English to High School Speakers of Arabic in Israel. Discourse and Society Journal, 26 (5), 517-542.

Cortazzi, Martin dan Jin, Lixian. Cultiral Mirrors, Materials and Method in the EFL Classroom in Eli Hinkel. (1999). Culture in Second Language Teaching and Learning. Cambridge: Cambridge University Press.

Ndurra, Elavie. (2004). ESL and Cultural Bias: an Analysis of Elementary Through High School Textbooks in the Western United States of America, Language, Culture and Curriculum Journal, 17 (2), 143-153.

Fairlough, Norman. (1995). Critical Discourse Analysis, The Critical Study of Language. New York: Longman Group Ltd.

Gorjian, B. \& Aghvami, F. (2017). The Comparative Study of EFL Teachers and Learners' Perceptions on the Im- portance of Teaching Culture. Applied Linguistics and Language Learning Journal, 3 (3), 71-78.

Harmer, Jeremy. (2007). The Practice of English Language Teaching. Edinburg: Pearson.

Kramsch, Claire. (1998). Language and Culture. New York: Oxford University Press.

Rodriguez, Luis F.G. Rodriguez. (2015). The Cultural Content in EFL Textbooks and What Teachers Need to Do about It. Profile Journal, 17 (2), 167-187.

Matsumoto, David \& Juang, Linda. (2013). Culture and Psychology, $5^{\text {th }}$ Edition. Canada: Wadsworth, Cengage Learning.

Yaqoob M. Tahir \& Zubair, Shirin. (2012). Culture, Class and Power: A Critique of Pakistan English Language Textbooks, Pakistan Journal of Social Sciences, 32 (2), 529-540.

Nieto, Sonia. (2010). Language, Culture, and Teaching; Critical Perspectives. New York: Routledge.

Reisinger, Yvette \& Turner, Lindsat. (2003). Cross Cultural Behaviour in Tourism: Concepts and Analysis. Oxford: Butterworth Heinemann.

Sidhakarya, I Wayan \& Pratiwi, D.P. Eka. (2015). Cultural Values as Catalysts in Learning a Foreign Language. Proceedings: The 62 ${ }^{\text {th }}$ TEFLIN International Conference 2015, 14-16 September 2015.

Suriasumantri, Jujun S. (2005). Filsafat Ilmu, Sebuah Pengantar Populer.

Jakarta: Pustaka Sinar Harapan.

Syahri, Indawan \& Susanti. (2016). An Analysis of Local and Target Culture Integration in the English Textbooks for Senior High School in Palembang. Journal of Education and Human Development, 5 (2), 97-102.

Tajeddin, Zia \& Teirmournezhad, Shohreh. (2015). Exploring the Hidden Agenda in the Representation of Culture in International and Localised ELT Textbooks. The Language Learning Journal, 43 (2), 180-193.

Yuen, Ka Ming. (2011). The Representation of Foreign Cultures in English Textbooks. ELT Journal Advance Access, 65 (4), 458-466.

\section{APPENDIX 1}

\section{Three English Coursebooks' Cover}
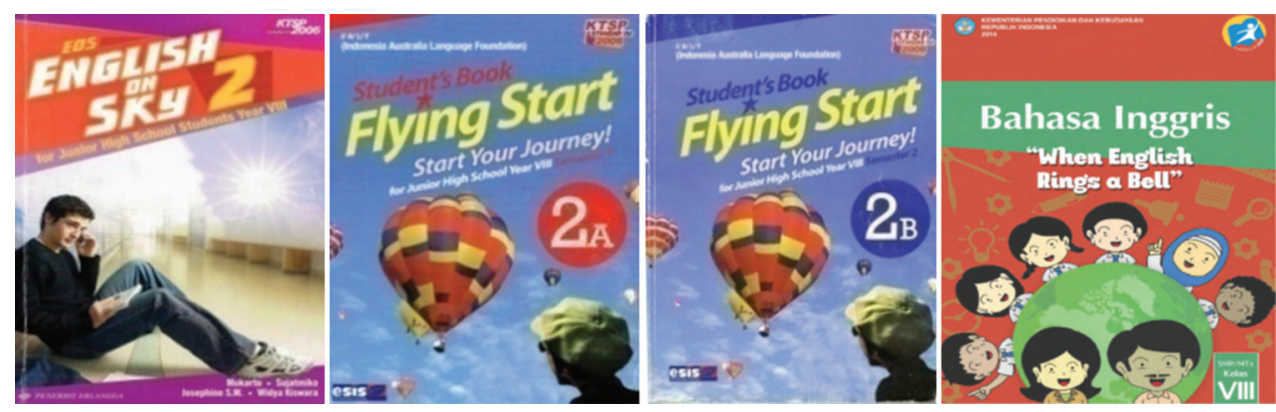
Profiles of Three English Coursebooks

\begin{tabular}{lllcl}
\hline Num & Title & Authors & Units/Pages & Publication/Year \\
\hline 1 & English on Sky (EOS) 2 for & Mukarto & 8 unit/206 & Erlangga 2007 \\
& Junior High School Year VIII & Sujatmiko & & \\
& KTSP Standar Isi 2006 & Widya Kiswara & & \\
& & Tim I/A/L/F & 7 unit/2A: 193 & ESIS/Erlangga 2007 \\
2 & Flying Start - Start Your & Jeanette & 2B: 161 & \\
& Journey 2A \& 2B for Junior & Lindsay-Clark & & \\
& High School Year VIII & Agnes Shanti & & \\
& KTSP Standar Isi 2006 & Nindyarini & & Indonesia Education and \\
& & Rahma Diana Sari & & Culture Department 2014 \\
& & Siti Wachidah & 12 unit/232 & \\
\end{tabular}

